\title{
Classification of Internet Language Learning Resources Based on Bloom's Taxonomy and the Four Language Skills
}

\author{
Ajeng Hidayatul Maghdalena ${ }^{1}$, Mokhamad Syaifudin ${ }^{2}$, Irma Soraya ${ }^{3}$ \\ English Education Department \\ UIN Sunan Ampel Surabaya \\ Surabaya, Indonesia \\ ajeng100894@gmail.com¹, msyaifudin@uinsby.ac.id², mozafyr@yahoo.com ${ }^{3}$
}

\begin{abstract}
In this modern era, teacher should recognize the trend toward the use of internet that has been widely applied in language teaching. The use of World Wide Web over past decade has been dramatically increasing in education. It means that teacher should realize the innovation in teaching environment which can be done by using internet. Furthermore, due to the rapid development of internet language resources in this modern era, the teachers need to keep up the expanding of them. The way to keep up is classifying the internet language learning resources based on certain categories. In this study, cognitive development based on bloom's taxonomy and the four language skills are the clear categories for classifying the internet language learning resources. In particular, 61 web resources which were taken from Agarwal's study were analyzed through a set of criteria which have been adapted and modified from some theoretical sources. After analyzing those web resources, there are 39 web resources that belong to categories associated with the cognitive development based on bloom's taxonomy and the four language skills. It means that there are $64 \%$ web resources that can be guidance and assistance for the language teachers to explore those web resources and choose the right ones for their teaching purposes. Therefore, during analyzing Agarwal's study, the researcher fond that the web resources that came from his study can be classified based on bloom's taxonomy and the four language theories.
\end{abstract}

Keywords-gamification; Internet Language Learning Resources, Language Learning Materials, Bloom's taxonomy.

\section{INTRODUCTION}

Nowadays, the development of technology and internet has been widely applied in education. The use of World Wide Web over the past decade has been dramatically increase because of the use of modern technology in teaching languages [10]. With the development of technology and the Internet in education, it is possible now to study with distance learning using internet to link between students and teacher. Then, they may interact with others in different locations by using technology. It means that teacher should recognize the trend toward the use of internet in this modern era. They should realize that the innovation in teaching environment can be done by using internet, because today's students are facing the virtual world [11]. Furthermore, according to Chih-hung, a young teacher of writing and CALL says that by using internet, it can increase the use of electronic document and save papers, because the use of hard-copy documents has been burden for institution, teachers, and the environment [11].

In term of recognizing the trend of the use of technology and internet in education, a curriculum of English Teacher Education Department in Islamic University of Sunan Ampel Surabaya also applies the development of technology and internet in educational side. The proof is the existence of CALL (Computer-Assisted Language Learning) class in sixth semester. This class is preparing students in designing materials and media by using technology and internet that can be applied in teaching-learning process. All of the materials are required students to learn about the newest technology to improve language skills. Many internet language learning resources are introduced during this program in a semester and it provides between the teachers and students with creative and practical ideas, for the example is providing links to go to the various addresses and the students only need clicking those addresses.

However, according to a preliminary research on five students in sixth semester who are joining in CALL class, the researcher asked their opinion about the benefit of using internet in education, especially for their teaching practice or their real teaching. Based on their answers, it can be concluded that most of them mention the benefit of using technology and internet, but they also mention the difficulties to use it, such as they still getting confused to find out the appropriate materials with their teaching purposes, because since very often the results of the searching in internet language learning resources are so vast and not focused. Moreover, teacher should use internet language learning resources as an empowering tool to improve their language abilities, especially for their language skills. It is in line with Lin's explanation, she says that today it has been a necessary basic quality and ability for people to search for information using internet resources [1]. It means that teacher needs the assistance to keep up the expanding internet language resources, such as classifying the internet language resources based on certain categories. By classifying the internet language resources, it can be guided the language 
teacher to explore those resources and choose the right ones for their teaching purposes.

Related with classification of internet language learning resources based on certain categories, the researcher chooses the classification of internet language learning resources based on bloom's taxonomy and the four language skills. In term of bloom's taxonomy, cognitive development is a part of bloom's taxonomy. Then, according to Kathryn Zawisza's explanation, bloom's taxonomy is a powerful tool to help develop learning objectives, because it explains the process of thinking [5].

\section{INTERNET LANGUAGE LEARNING RESOURCES}

Talking about internet language learning resources, Johnstone has a statement about it. He says that internet language learning resources is anything that can be used to organize and support learning and teaching process that consist of tools for teachers and support materials to enable them to create and adapt it [8].

Besides, on 1st February 2010, there is a study about internet-based language learning and teaching which is conducted by Agarwal as the teacher of Riga Technical University. This university is not only focused on providing high quality education, but also conducts advanced research and innovation and technology. Therefore, it can be concluded that both of technology and education have relation for increasing and improving education, especially for EFL teaching process. On his study, he tries to classify many kinds of internet language learning resources on his web-site. He classifies those web resources become seven categories, such as my favourites, my test, video lessons, grammar, listening, reading, and some more, which has different contents for each table. This table can be found on (http://www.englishtests.webs.com/).

Moreover, both of teacher and learners can not only find online dictionaries, games, a chat site, quizzes for defining the level of English language knowledge, but also the various of English test with the explanations. Besides, there are some international web-site as internet language learning resources are included on this web-site, such as British Council. According to British Council web-site, British Council is the UK's international organization for cultural relations and educational opportunities. Then, their work in English purposes is to bring high-quality language materials to every learner and teacher who wants them. Besides, they can teach English and train teacher through radio, web and television broadcasts. Therefore, that is a reason why the researcher choose this web-site, because the table consist of many kinds of English materials. The table of language materials on the web-site are appear below:

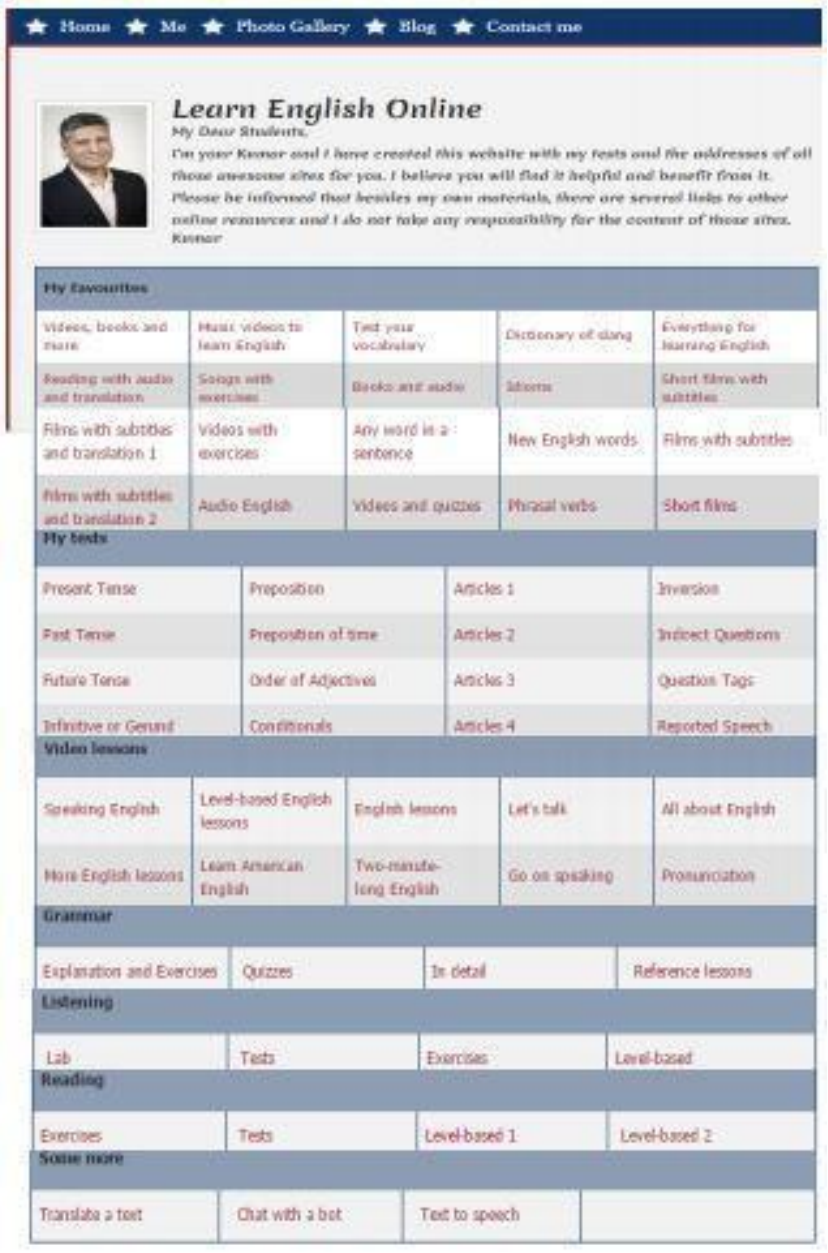

Fig. 1. Agarwal's Web Resources (Learn and Test English with Dr. Kumar).

\section{LANGUAGE LEARNING MATERIALS.}

Based on Materials Development in Language Teaching book, the definition of language learning material is anything which is used by teachers or learners to facilitate the learning of a language [3]. The materials can be cassettes, videos, CD-ROMs, dictionaries, grammar books, newspaper, native speaker, internet resources, etc. In short, they can be anything which is used to improve the learners' knowledge or experience of the language. Therefore, related with this study teacher can use the internet language learning resources as the teaching materials by selecting and choosing it based on their teaching purposes that will be classified based on classification of bloom's taxonomy and the four language skills.

\section{BLOOM'S TAXONOMY: ORIGINAL AND REVISED}

\section{A. The Original Taxonomy Of Cognitive Domain}

In 1956, Bloom said that the cognitive domain involves knowledge and the development of intellectual skill. Cognitive domain is included in recalling specific facts, procedural patterns, and concepts that serves in the development of intellectual abilities and skills [4]. There are six categories of cognitive domain which is starting from the simplest ability to 
the most complex ability, or it can be called as degrees of difficulties. In an effort to decrease the confusion of the six level of bloom's taxonomy, the figure of cognitive domain are appear below:

\begin{tabular}{|c|c|c|c|}
\hline Category & Key Wo & ds (Verbs) & \\
\hline $\begin{array}{l}\text { Knowledge: } \\
\text { Recall data or information }\end{array}$ & $\begin{array}{l}\text { Arranges } \\
\text { Defines } \\
\text { Describes } \\
\text { Identifies } \\
\text { Knows }\end{array}$ & $\begin{array}{l}\text { Labels } \\
\text { Lists } \\
\text { Matches } \\
\text { Names } \\
\text { Outlines }\end{array}$ & $\begin{array}{l}\text { Recalls } \\
\text { Recognizes } \\
\text { Reproduces } \\
\text { Selects } \\
\text { States }\end{array}$ \\
\hline $\begin{array}{l}\text { Comprehension: } \\
\text { Understand the meaning, translation, } \\
\text { interpolation, and interpretation of instruction and } \\
\text { problems. State a problem in one's own words. }\end{array}$ & $\begin{array}{l}\text { Comprehends } \\
\text { Converts } \\
\text { Defends } \\
\text { Generalizes } \\
\text { Give }\end{array}$ & $\begin{array}{l}\text { An example } \\
\text { Infers } \\
\text { Interprets } \\
\text { Paraphrases } \\
\text { Predicts }\end{array}$ & $\begin{array}{l}\text { Rewrites } \\
\text { Summarizes } \\
\text { Translates. }\end{array}$ \\
\hline $\begin{array}{l}\text { Application: } \\
\text { Use a concept in a new situation or unprompted } \\
\text { use of an abstraction. Applies what was learned in } \\
\text { the classroom into novel situations in the work } \\
\text { place. }\end{array}$ & $\begin{array}{l}\text { Applies } \\
\text { Changes } \\
\text { Computes } \\
\text { Constructs } \\
\text { Demonstrates }\end{array}$ & $\begin{array}{l}\text { Discovers } \\
\text { Manipulates } \\
\text { Modifies } \\
\text { Operates } \\
\text { Predicts }\end{array}$ & $\begin{array}{l}\text { Prepares } \\
\text { Produces } \\
\text { Relates } \\
\text { Shows } \\
\text { Solves } \\
\text { Uses }\end{array}$ \\
\hline $\begin{array}{l}\text { Analysis: } \\
\text { Separates material or concepts into component } \\
\text { parts so that its organizational structure may be } \\
\text { understood. Distinguishes between facts and } \\
\text { inferences. }\end{array}$ & $\begin{array}{l}\text { Analyses } \\
\text { Breaks down } \\
\text { Compares } \\
\text { Contrasts } \\
\text { Diagrams }\end{array}$ & $\begin{array}{l}\text { Deconstructs } \\
\text { Differentiates } \\
\text { Discriminates } \\
\text { Distinguishes } \\
\text { Identifies } \\
\text { Illustrates }\end{array}$ & $\begin{array}{l}\text { Infers } \\
\text { Outlines } \\
\text { Relates } \\
\text { Selects } \\
\text { Separates }\end{array}$ \\
\hline $\begin{array}{l}\text { Synthesis: } \\
\text { Builds a structure or pattern from diverse } \\
\text { elements. Put parts together to form a whole, with } \\
\text { emphasis on creating a new meaning or structure. }\end{array}$ & $\begin{array}{l}\text { Categorizes } \\
\text { Combines } \\
\text { Compiles } \\
\text { Composes } \\
\text { Creates } \\
\text { Devises } \\
\text { Designs }\end{array}$ & $\begin{array}{l}\text { Explains } \\
\text { Generates } \\
\text { Modifies } \\
\text { Organizes } \\
\text { Plans } \\
\text { Rearranges } \\
\text { Reconstructs }\end{array}$ & $\begin{array}{l}\text { Relates } \\
\text { Reorganizes } \\
\text { Revises } \\
\text { Rewrites } \\
\text { Summarizes } \\
\text { Tells } \\
\text { Writes }\end{array}$ \\
\hline $\begin{array}{l}\text { Evaluation: } \\
\text { Make judgments about the value of ideas or } \\
\text { materials. }\end{array}$ & $\begin{array}{l}\text { Appraises } \\
\text { Compares } \\
\text { Concludes } \\
\text { Contrasts } \\
\text { Criticizes }\end{array}$ & $\begin{array}{l}\text { Critiques } \\
\text { Defends } \\
\text { Describes } \\
\text { Discriminates } \\
\text { Evaluates } \\
\text { Explains }\end{array}$ & $\begin{array}{l}\text { Interprets } \\
\text { Justifies } \\
\text { Relates } \\
\text { Summarizes } \\
\text { Supports }\end{array}$ \\
\hline
\end{tabular}

Fig. 2. The Original of Bloom's Taxonomy

\section{B. The Revised of Bloom's Taxonomy}

In 2001, a former student of Bloom's, Lorin Anderson, and a group of cognitive psychologists, curriculum theorists and instructional researchers, and testing and assessment specialists published a revision of Bloom's Taxonomy entitled A Taxonomy for Teaching, Learning, and Assessment [4].

\begin{tabular}{|c|c|c|c|}
\hline \multirow{4}{*}{\begin{tabular}{l}
\multicolumn{1}{c}{ Category } \\
Remembering: \\
Shallow processing: drawing out factual answers, \\
testing recall and recognition.
\end{tabular}} & \multicolumn{2}{|c|}{ Key Words (Verbs) } & \multirow[b]{2}{*}{ Recite } \\
\hline & Choose & Locate & \\
\hline & Describe & Match & Recognize \\
\hline & Define & Memorize & Select \\
\hline & Identify & Name & State \\
\hline & Label & Omit & \\
\hline & List & & \\
\hline \multirow{8}{*}{$\begin{array}{l}\text { Understanding: } \\
\text { Comprehending the meaning, translation, } \\
\text { interpolation and interpretation of instructions and } \\
\text { problems. State a problem in one's own words. }\end{array}$} & Classify & Illustrate & Represent \\
\hline & Defend & Indicate & Restate \\
\hline & Demonstrate & Interrelate & Rewrite \\
\hline & Distinguish & Interpret & Select \\
\hline & Explain & Infer & Show \\
\hline & Express & Judge & Summarize \\
\hline & Extend & Match & Tell \\
\hline & Give example & Paraphrase & Translate \\
\hline Applying: & Apply & Organize & Show \\
\hline \multirow{4}{*}{$\begin{array}{l}\text { Knowing when to apply, why to apply, and } \\
\text { recognizing patterns of transfer situations that are } \\
\text { new, unfamiliar or have a new slant for students. }\end{array}$} & Choose & Paint & Sketch \\
\hline & Dramatize & Prepare & Solve \\
\hline & Explain & Produce & Use \\
\hline & $\begin{array}{l}\text { Generalize } \\
\text { Judge }\end{array}$ & Select & \\
\hline Analyzing: & Analyse & Differentiate & Point out \\
\hline \multirow[t]{3}{*}{ Breaking down into parts, forms. } & Categorize & Distinguish & \\
\hline & Classify & Identity & Subdivide \\
\hline & Compare & Infer & Survey \\
\hline Evaluating: & Appraise & Criticize & Compare \\
\hline According to some set of criteria and state it why & Judge & Defend & \\
\hline Creating: & Choose & Develop & Make up \\
\hline \multirow{5}{*}{$\begin{array}{l}\text { Combining elements into a pattern not clearly } \\
\text { there before. }\end{array}$} & Combine & & Originate \\
\hline & Compose & Formulate & Organize Plan \\
\hline & Construct & Hypothesize & Produce \\
\hline & Create & Invent & Role play \\
\hline & Design & Make & Tell \\
\hline
\end{tabular}

Fig. 3. The Revised of Bloom's Taxonomy
The graphic below illustrates the differences between Bloom's original taxonomy and the 2011 revised taxonomy [9]:

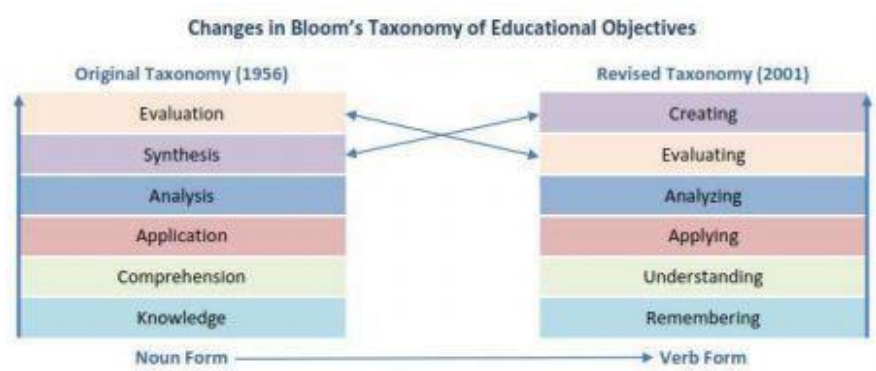

Fig. 4. Changes in Bloom's taxonomy of Educational Objectives.

The most obvious differences between the 1956 and 2001 versions is in revising the taxonomy between evaluation and synthesis. The highest level is not the evaluation, but a new category of creating becomes the highest level. This category was originally recognized as synthesis. Another significant change is the category names. Changing the name of six categories is in noun form becomes the verb form.

Then, according to Zawisza's explanation, she said that bloom's taxonomy is the powerful tool to help develop learning objectives, because it explains the process of thinking [5]. Therefore, in this study the researcher used the categories of bloom's taxonomy to identify the internet language learning resources.

\section{Classifying The Internet Language Learning Resources Based on Bloom's Taxonomy}

As stated previously, the objective of this study is to know the classification of internet language learning resources which are able to facilitate the students' cognitive development based on bloom's taxonomy and the four language skills. Furthermore, in order to achieve the objective of the study, the researcher have analyzed 61 web resources which were taken from Agarwal's study by using the instrument.

After analyzing those web resources, there are 39 web resources that belong to categories associated with the cognitive development based on bloom's taxonomy and the four language skills. It means that there are $64 \%$ web resources that can be guidance and assistance for the language teachers to explore those web resources and choose the right ones for their teaching purposes. This statement is in line with according to Zawisza's explanation, bloom's taxonomy is a powerful tool to help develop learning objectives, because it explains the process of thinking [5]. Therefore, based on the research finding in this study, the researcher classified 39 web resources into the table of classification of internet language learning resources based on bloom's taxonomy and the four language skills.

According to the classification of internet language learning resources based on bloom's taxonomy and the four language skills, the researcher interpreted that https://lingualeo.com is the most appropriate web resource for students' cognitive development based on bloom's 
taxonomy and the four language skills. The content of this web resources fulfill all six level on bloom's taxonomy and the four language skills categories completely. In bloom's taxonomy, it consist of remembering, understanding, applying, analyzing, evaluating and creating.

Additionally, there are 22 web resources that do not belong to any categories associated with the cognitive development based on bloom's taxonomy and the four language skills since the content of those web resources are about vocabularies and English grammar without any instructions of the four language skills, because when the grammar instructions are taught separately with the language skill instructions, it cannot be entered in the table of classification of internet language learning resources based on bloom's taxonomy and the four language skills. This statement was in line with Hillocks and Braddock's statement, they said that students' skills competence does not improve when the grammar instructions are taught separately with the language skills instructions [2]. Therefore, the web resources that only consist of grammar without any instruction of the four language skills were not classified into any categories of bloom's taxonomy and the four language skills.

\section{Web Resource for Reading Skill that Facilitate Cognitive Development Based on Bloom's Taxonomy.}

web

According to research finding for reading skill's

(http://learnenglishteens, britishcouncil.org/skills/readingskillspractice), the reading passage describe the exciting range of holidays. Then, the learners is leaded to match, select, and identify the questions in 5 grouping exercises. Besides, the learners is leaded also to choose, memorize, recognize, and infer for answering the 12 multiple choice exercises. It means that, according to theory of cognitive development based on bloom's taxonomy, this web resource can be entered in remembering and understanding level, such as describe, identify, memorize, and recognize. Then, the keywords of infer, match, and select is included in understanding level. It can be identified from the instructions "choose, and check your understanding". (See figure 5) Then, the questions of the multiple choice exercises, such as "can you see..." Those words can represent the level of remembering and understanding level based on bloom's taxonomy. Further, related to remembering and understanding level, this web resource introduce and build foundational knowledge of English. This statement is in line with Shabatura's statement, she said that remembering and understanding level may be used as the objective of learning process for introducing and building the foundational knowledge of the freshman [7].

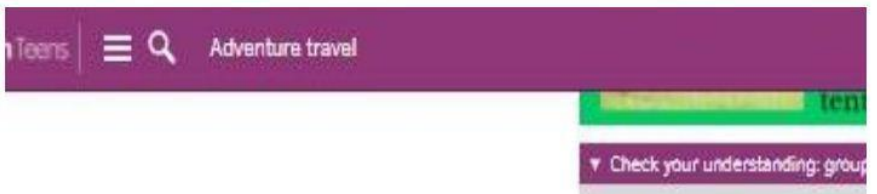

Fig. 5. Instruction on Reading Exercises

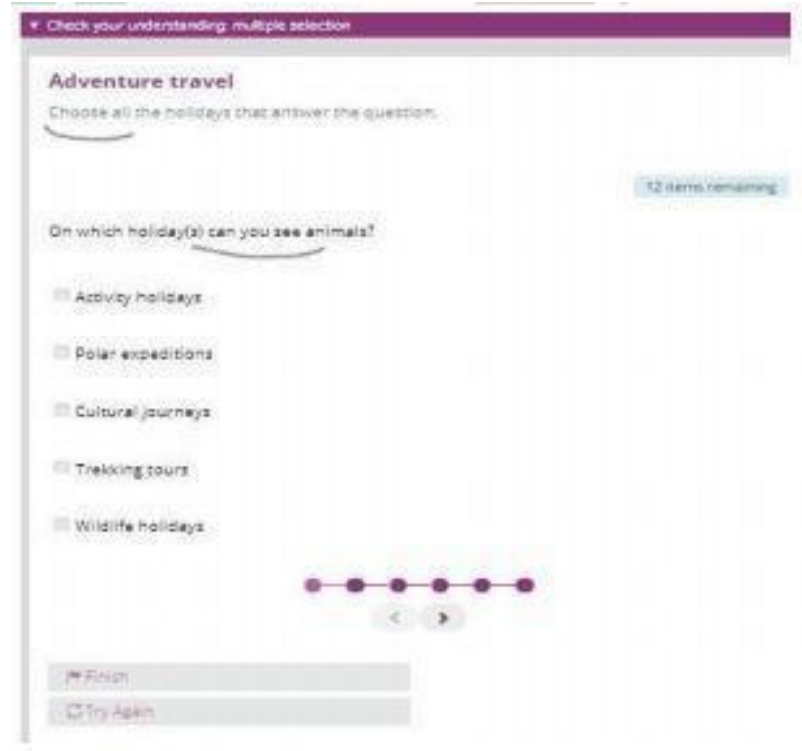

Fig. 6. Instruction and Question

\section{Web Resource for Listening Skill that Facilitate Cognitive Development Based on Bloom's Taxonomy.}

Regarding to web resource for listening skill and cognitive development based on bloom's taxonomy, the researcher analyze 7 multiple choice exercises based on the audio file.

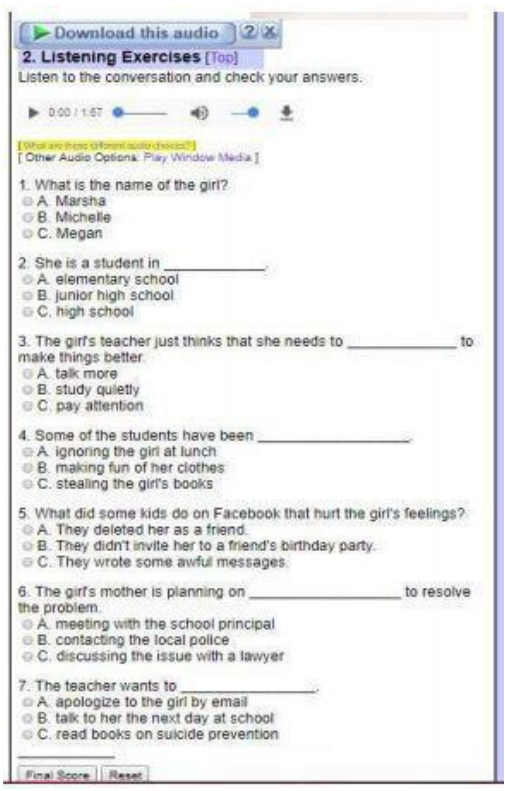

Fig. 7. Multiple Choice Exercises

Those questions represent the keywords on remembering and understanding levels, because those questions recalling memory what they have heard from the audio. Learners should choose, because the items are multiple choices. Identify, memorize, recognize, select, interrelate, and interpret to answer those questions. 


\section{Web Resource for Writing Skill that Facilitate Cognitive Development Based on Bloom's Taxonomy.}

According to research findings, the content of the web resource is only define the definition of the types of the text, explain the generic structure and give example the transitional words in the text. Related to theory of bloom's taxonomy, this web resource is included in remembering and understanding level, because the keywords of remembering level is define, where this web resource is define the definition of the types of the text. Besides, the keywords of understanding level are explain and give example. It means that, when the web resource explains the generics structure and give example, the understanding level is represented. It can be proof with these sentences.

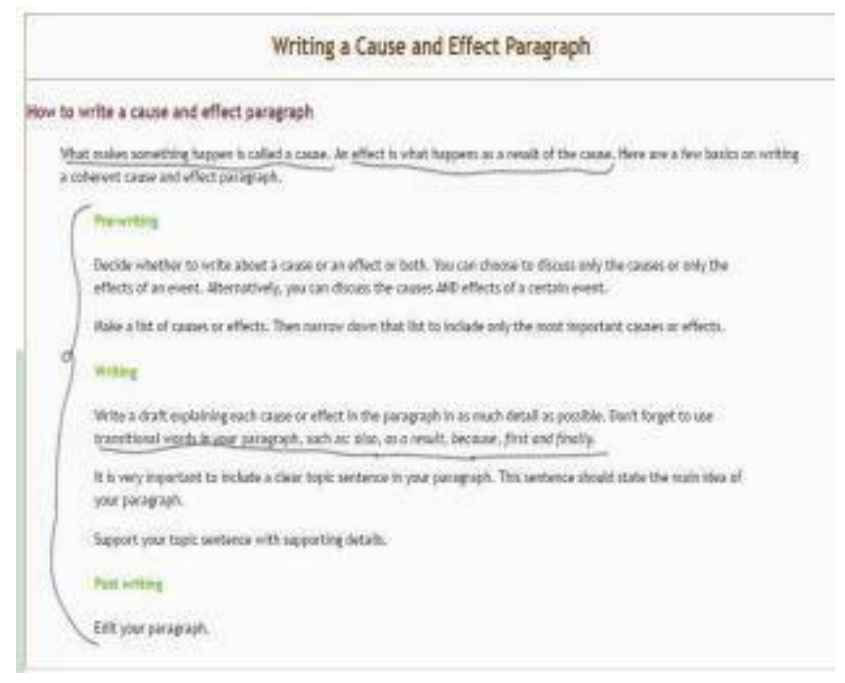

Fig. 8. Writing a Cause and Effect Paragraph

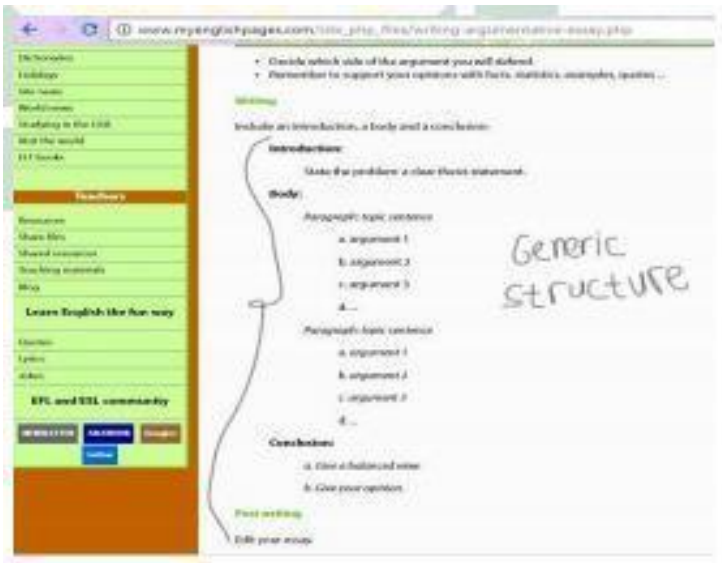

Fig. 9. The Generic Structure of Argumentative Essay.

\section{Web Resource for Speaking Skill that Facilitate Cognitive Development Based on Bloom's Taxonomy.}

Dealing with research findings, the researcher found that this web resource represents remembering, understanding, applying and creating level based on the theory of bloom's taxonomy. In remembering level, the audio of web resource leads the learners to recognize, memorize, state and identify how to pronounce those sentences based on the dialog while reading the text and identify the pronunciation. It means that the web resource represents the keywords of remembering, such as recognize, memorize, state and identify. Then, it can be found that the audio expresses the sentences, giving example how to pronounce it, restate the sentences in the part of role play dialog, show and tell the sound of each word and sentence in the dialog are the content of web resource. It means that, the keywords of understanding levels are represented, such as express, giving example, restate, show, and tell. Further, because of in the role-play dialog the learners should do, tell, and roleplay as the next speaker, those activities are represent the keywords of creating level, such as do, tell, and role play.

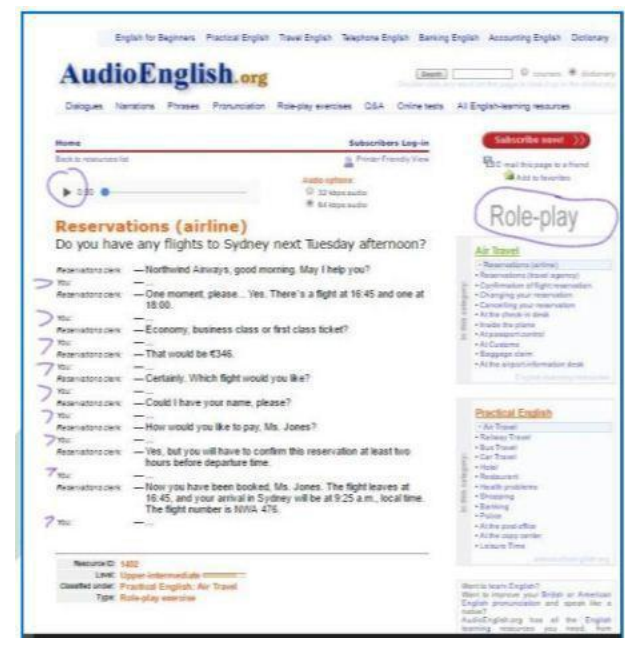

Fig. 10. Role-Play Dialog.

Moreover, related to the research findings there were $74 \%$ web resources that facilitate the first and the second level of bloom's taxonomy. Those are remembering and understanding. According to Shabatura's statement, she said that the level of bloom's taxonomy may be used as the objective of learning process for introducing and building the foundational knowledge of the freshman. Those are remembering and understanding level [7]. It is proven from all the tables in findings that are shown the most available of the web resources are recalling, recognizing and comprehending the English materials for the learners. In other word, remembering and understanding level of bloom's taxonomy are to introduce and build foundational knowledge of English.

\section{CONCLUSION}

The researcher found that the web resources can be classified based on bloom's taxonomy and the four language skills. Due to the rapid development of internet language resources in this modern era, the teachers need to keep up the expanding of them. The way to keep up is classifying the internet language learning resources based on certain categories. In this study, cognitive development based on bloom's taxonomy and the four language skills are the clear categories for classifying the internet language learning resources. By classifying those web resources, it can become guidance for the language teacher to explore those resources and choose the right ones for their teaching purposes.

Being teacher in this modern era, recognizing the trend towardthe use of internet that has been widely applied in language teaching is needed. The use of World Wide Web over 
the past decade has been dramatically increasing in education. It means that teacher should realize the innovation in teaching environment which can be done by using internet, for the example is using the English materials that are taken from the internet language learning resources based on bloom's taxonomy and the four language skills.

\section{REFERENCES}

[1] Eleonora Villegas and Reimers. Teacher Professional Development: An International Review of Literature (Paris:International Institue For Educational Planning, 2003).

[2] Beverly Ann Chinn, "The Role of Grammar In Improving Student's Writing" (https://people.uwplatt.edu/-ciesield/graminwriting.htm. accessed on June 04, 2017)

[3] Brian Tomlinson, "Materials Development in Language Teaching", (Cambridge

University Press: 1998), 2

[4] Forehand, M. "Bloom's taxonomy: Original and revise" (http://www.coe.uga.edu/epltt/bloom.htm, accessed on November 29, 2016
[5] Kathry Zawisza, "Using Bloom's Taxonomy to Write Effective Learning Objectives", (https://tips.uark.edu/using-blooms-taxonomy/ accessed on 11 June 2017)

[6] Kathryn Zawisza. "Using Bloom's Taxonomy to Write Effective Learning Objectives" Teaching Innovation \& Pedagogical Support, (https://Tips.Uark.Edu/Using-BloomsTaxonomy/, Accessed On June 14th, 2017)

[7] Kathryn Zawisza. "Using Bloom's Taxonomy To Write Effective Learning Objectives" Teaching Innovation \& Pedagogical Support, (Https://Tips.Uark.Edu/Using-BloomsTaxonomy/, Accessed On June 15th, 2017)

[8] Rupert Herington, "Teaching Efl/Esl Students How To Use Search Engines And Develop Their English", Vol. Viii, No. 12, December 2002

[9] The International Assembly for Collegiate Business Education, Bloom's Taxonomy

Educational Objectives and Writing Intended Learning Outcomes Statements ( Lenexa, KansasUSA, 2014-2016), 4

[10] Yu-li Chen Ã, "A mixed-method study of EFL teachers' Internet use in language instruction", Vol.24, Taiwan: 2008, 1016

[11] Yu-li Chen Ã, "A mixed-method study of EFL teachers...1022 